\title{
ANALISIS PENGARUH MANAJEMEN RELASIONAL TERHADAP LOYALITAS NASABAH DENGAN KETERIKATAN NASABAH SEBAGAI VARIABEL INTERVENING
}

\author{
Waika Yury Elianto'), Sri Murni Setyawati'), Refius P Setyanto') \\ 1)Program Pascasarjana Magister Manajemen Universitas Jendral Soedirman Purwokerto \\ *Email corresponding author : waikayuryelianto@gmail.com
}

\begin{abstract}
Abstrak
Masalah dalam penelitian ini adalah tentang loyalitas nasabah perbankan di Purwokerto. Penelitian ini bertujuan untuk menguji dan menganalisis pengaruh customer relationship management dan customer engagement terhadap loyalitas nasabah, menguji dan menganalisis pengaruh customer relationship management terhadap customer engagement serta menguji peran customer engagement sebagai variabel mediasi antara customer relationship management dengan loyalitas nasabah. Penelitian dilakukan terhadap 144 nasabah prioritas Bank BCA Cabang Purwokerto. Teknik analisis data yang digunakan adalah stuctural equation modelling (SEM) dengan softwate AMOS. Kesimpulan dari penelitian ini adalah customer relationship management dan customer engagement berpengaruh positif terhadap loyalitas nasabah. Customer relationship management berpengaruh positif terhadap customer engagement. Customer engagement berfungsi sebagai variabel mediasi antara customer relationship management dengan loyalitas nasabah.
\end{abstract}

Kata Kunci : Manajemen relasional nasabah, keterikatan nasabah, Loyalitas nasabah

\begin{abstract}
The problem in this research is about loyalty to banks in Purwokerto. This aims of this research to discuss and analyze customer management relationships and customer engagement with customer loyalty, discuss and analyze customer management relationships with customer engagement and help customer engagement as a mediating variable between customer relationship management and customer loyalty. The study was conducted on 144 priorities of BCA Bank Purwokerto Branch. The data analysis technique used is structural equation modeling (SEM) with AMOS software. The conclusion of this study is that customer relationship management and customer engagement are considered positive for customer loyalty. Customer relationship management has a positive effect on customer engagement. Customer engagement works as a mediating variable between customer relationship management and sales loyalty.
\end{abstract}

Keywords: Customer relationship management, customer engagement, customer loyalty

\section{PENDAHULUAN}

Era globalisasi dan teknologi informasi menjadikan persaingan bisnis semakin kompetitif. Bermunculan pesaing baru dalam industri, menjadi ancaman bagi perusahaan. Perkembangan teknologi dan munculnya persaingan tersebut terjadi juga dalam industri perbankan. Adanya persaingan dalam industri perbankan, berdampak baik bagi nasabah, yaitu bank akan bersaing untuk memberikan pelayanan terbaik agar dapat menarik nasabah dan meningkatkan pangsa 
pasar. Kemudahan dalam mengakses fasilitas perbankan, menjadikan konsumen dapat membedakan kualitas pelayanan antara bank satu dengan dengan bank lainnya. Dalam kompetisi saat ini perusahaan yang dapat memberikan kualitas layanan terbaik dan konsumen merasa puas, maka perusahaan tersebut akan survive. Kepuasan tersebut akhirnya membuat konsumen menjadi loyal (Jiang \& Zhang, 2016).

Loyalitas adalah kemauan yang kuat untuk membeli atau menjadi pelanggan bagi produk atau jasa tertentu di masa mendatang (Kotler \& Keller, 2007). Hal yang melatarbelakangi perusahaan untuk mempertahankan kesetiaan konsumen adalah karena biaya akuisisi pelanggan baru dalam persaingan yang semakin ketat menjadi cukup mahal. Loyalitas adalah kemauan kuat dari konsumen untuk menjadi pelanggan tetap atau membeli kembali produk atau jasa yang diminati secara konsisten di masa datang, sehingga ada kesediaan melakukan konsumsi merek yang sama, walaupun kegiatan pemasaran dan pengaruh situasi bisa menjadikan seseorang berperilaku beralih pada brand lain (Tjiptono, 2005).

Faktor yang mempengaruhi kesetiaan pelanggan yaitu kepuasan (satisfaction), ikatan emosi (emotional bonding), kepercayaan (trust), pengurangan pilihan dan kebiasaan (choice reduction and habit) dan pengalaman dengan perusahaan (experience with company) (Vanessa, 2007). Konsep loyalitas menitikberatkan pada perilaku (behavior) daripada sikap (attitude) dan kesetiaan konsumen menggambarkan perilaku pembelian dengan pola yang terus menerus dalam tempo yang lama.

Disamping itu terdapat faktor lain yang berpotensi mempengaruhi kesetiaan pelanggan adalah hubungan baik antara perusahaan dengan pelanggan yaitu melalui jalinan komunikasi yang dibangun secara baik dengan para relasi bisnis tersebut. Customer relationship management adalah salah satu pengetahuan terbaru yang cukup menarik akhir-akhir ini. Dengan CRM, perusahaan akan memperoleh informasi detil mengenai para pelanggan. Informasi tersebut berupa data pribadi pelanggan, saran, kritik, dan semua hal yang dibutuhkan oleh pelanggan. Manajemen hubungan pelanggan adalah strategi terukur dan tepat untuk mendukung penerapan Customer to Business atau Customer to Customer yang dilakukan perusahaan.

Penerapan strategi CRM sangat penting, selain karena dapat meningkatkan pelayanan kepada pelanggan juga memperbaiki dan mengelola pelanggan sesuai ekspektasi dan kesetiaan pelanggan. Implementasi CRM dapat memberikan layanan pelanggan yang lebih baik, serta peningkatan dan pengelolaan harapan dan loyalitas pelanggan (Cho, Im, Hiltz, \& Fjermestad, 2001; Salami, 2009). Hal ini sesuai penelitian yang dilakukan oleh Lee-Kelley, Gilbert, and Mannicom (2003) yang menyatakan bahwa persepsi konsumen terhadap manajemen hubungan pelanggan yang dikelola secara elektronik dapat meningkatkan loyalitas pelanggan, sedangkan persepsi konsumen terhadap manajemen hubungan pelanggan dipengaruhi oleh usaha pengecer untuk menerapkan hubungan pelanggan melalui internet (e-CRM).

Manajemen hubungan pelanggan dapat dilakukan untuk mengembangkan dan memelihara pelanggan dalam jangka panjang, yang bertujuan saling menguntungkan (Uppal, 2008). Manajemen hubungan pelanggan ini merupakan konsentrasi perusahaan untuk fokus layanan pada pelanggan. Inti dari inisiatif fokus pada pelanggan (customer-centric) adalah kepercayaan pemahaman kebutuhan pelanggan dan memberikan nilai lebih kepada pelanggan, bank dapat meningkatkan posisi persaingan kompetitif. Meskipun investasi manajemen hubungan pelanggan ini sangat besar, kritikus tetap tidak yakin tentang efektivitas upaya relasional dalam pengembangan pasar dan memenuhi hasil bisnis yang diinginkan. 
Manajemen hubungan pelanggan dianggap sebagai "solusi teknologi" spesifik (Payne \& Frow, 2005). Manajemen hubungan pelanggan dianggap memberikan solusi lebih baik daripada hanya mengintegrasikan kebutuhan pelanggan dengan strategi organisasi, orang dan proses bisnis (Sharma \& Goyal, 2011). Beberapa penelitian yang menjelaskan ukuran efektivitas CRM (CRME) berasal dari perspektif pemasok (Chen, Yen, Li, \& Ching, 2009). Hal ini membatasi pemahaman tentang bagaimana pelanggan memandang CRM dan hasil dari upaya hal tersebut pada perilaku mereka. Memahami perspektif pelanggan sangat penting untuk sebuah organisasi, karena CRM yang efektif membutuhkan proses bisnis dan teknologi yang fokus pada pelanggan. Apalagi, efektivitas CRM bervariasi tergantung dari strategi pemasaran hubungan dan situasi pertukaran (Palmatier, Dant, Grewal, \& Evans, 2006). Perbedaan budaya mempengaruhi persepsi dan perilaku relasional (Jham \& Khan, 2008), merekomendasikan pengukuran CRM dalam konteks budaya Timur seperti India. Selain itu, Soch and Sandhu (2008) berpendapat bahwa karena industri yang berbeda menunjukkan berbagai tingkat kinerja, sangat penting untuk mengukur CRM di industri perbankan.

Perusahaan harus melaksanakan suatu hubungan pemasaran pelanggan (customer relationship management) yang tepat. Sesuai dengan proses kegiatan pemasaran perusahaan, customer relationship management ditujukan pada pembentukan, pengembangan, dan pemeliharaan keberhasilan hubungan antara perusahaan dengan pelanggannya. Customer relationship management telah menjadi konsep pemikiran baru bagi strategi pemasaran. Customer relationship management mampu meningkatkan kekuatan keinginan konsumen dengan pengaruh pesatnya perubahan teknologi yang dapat memberikan kepuasan pada nasabahnya (Too, Souchon, \& Thirkell, 2001).

Ruang lingkup customer relationship management meliputi manajemen mutu terpadu dalam menghadapi perubahan kebutuhan bisnis dari pelanggan yang makin beragam dan agresif. Rangsangan yang akan diperlihatkan dari konsep customer relationship management adalah teknik-teknik terkini dalam upaya mencari perhatian, memelihara kepuasan nasabah serta meningkatkan dan mempererat hubungan perusahaan dengan pelanggan. Dengan kata lain, customer relationship management berupaya memperpanjang siklus hidup nasabah (Khoe, 1997). Customer relationship management adalah konsep pemasaran perusahaan yang mempunyai sasaran kepada nasabah dan membangun komunikasi pemasaran yang relevan (Blois, 1996). Customer relationship management menitikberatkan pada upaya menjalin hubungan dengan pelanggan satu demi satu. Hal ini memerlukan knowledge yang luas dan akurat dalam situasi, perilaku, kebutuhan dan preferensi nasabah. Penelitian tentang customer relationship management sarat akan anteseden, hasil, serta kegiatan proses pemasaran itu sendiri. Hubungan pemasaran pelanggan (customer relationship management) menawarkan semua aktifitas pemasaran mulai dari pendirian, pengembangan, dan pemeliharaan (Morgan \& Hunt, 1994).

Konsep customer relationship management berkembang sebagai sebuah filosofi manajemen yang mencakup konsep pemasaran dan hubungan jangka panjang dengan pelanggan dalam transaksi yang menguntungkan (Bennett, 1996). Ada tiga elemen penting yang terkait dengan proses relationship management yaitu mengidentifikasi dan membentuk database konsumen saat ini dan konsumen potensial, menyampaikan pesan berbeda yang didasarkan pada karakteristik dan preferensi konsumen, dan mengarahkan setiap hubungan untuk memonitor biaya akuisisi konsumen dan nilai seumur hidup dari pembeliannya (Copulsky \& Wolf, 1990).

Hubungan pelanggan dengan perusahaan yang sudah terjalin dengan baik menjadikan pelanggan memiliki keterikatan yang kuat pada perusahaan. Keterikatan ini akan 
menumbuhkan loyalitas pelanggan kepada perusahaan. Dasar-dasar konseptual yang muncul dari customer engagement berawal dalam teori pemasaran yang menangani hubungan dan pengalaman layanan interaktif (Brodie, Hollebeek, Jurić, \& Ilić, 2011). Hubungan pemasaran ditandai dengan interaktif, pengalaman pelanggan dengan pemangku kepentingan lain seperti perusahaan dan pelanggan lainnya, adalah inti munculnya konsep customer engagement (Vargo \& Lusch, 2008). Customer engagement adalah membangun perilaku yang melampaui transaksi, dan mungkin secara khusus didefinisikan sebagai manifestasi perilaku pelanggan yang memiliki merek atau fokus perusahaan di luar pembelian, yang dihasilkan dari dorongan motivasi, pandangan bersama oleh orang lain di lapangan (Bijmolt et al., 2010; Van Doorn et al., 2010).

Customer engagement dapat membawa kekuatan prediktif tambahan ke niat loyalitas ketika efek kepuasan, nilai yang dirasakan, dan kualitas yang dirasakan (Dwivedi, 2015). Ini menekankan nilai yang sangat besar bahwa konsep keterikatan dapat ditawarkan kepada akademisi dan praktisi dalam berbagai konteks. Konsep customer engagement perlu mempertimbangkan lebih dari fokus aktivitas murni, menggabungkan dimensi baik psikologis dan perilaku (Brodie et al., 2011). Secara khusus, untuk memperluas domain konseptual customer engagement, So, King, and Sparks (2014) berpendapat bahwa partisipasi dalam kegiatan customer engagement tidak berarti customer engagement benar-benar terkait dengan merek. Misalnya, pelanggan dapat terlibat dalam forum diskusi merek untuk berbagai alasan, seperti kebutuhan untuk informasi produk atau pengurangan risiko yang dirasakan, dan bukan dari yang terlibat atau terhubung ke merek. Oleh karena itu, pendekatan multidimensional disarankan untuk menangkap domain konseptual customer engagement. Sementara beberapa konseptualisasi multidimensi customer engagement telah diusulkan (Brodie, Ilic, Juric, \& Hollebeek, 2013; Hollebeek, 2011; So et al., 2014; Van Doorn et al., 2010).

Customer engagement dapat diartikan sebagai hubungan pelanggan secara pribadi untuk merek seperti yang digambarkan dalam respon kognitif, afektif dan perilaku di luar pembelian. Terdapat lima faktor utama dalam konsep customer engagement, yaitu antusiasme (atau semangat), perhatian, penyerapan, interaksi, dan identifikasi (So et al., 2014). Antusiasme merepresentasikan tingkat kegembiraan individu yang kuat terhadap merek, sedangkan perhatian menggambarkan perhatian konsumen dan fokus pada merek. Penyerapan ditandai dengan penuh terkonsentrasi dan menikmati saat berhubungan dengan merek. Interaksi mengacu pada partisipasi secara online dan offline pelanggan dengan merek atau pelanggan lain di luar pembelian. Akhirnya, identifikasi dirasakan individu sebagai rasa untuk memiliki merek. Lima dimensi yang mendasari, secara kolektif, mencerminkan aspek psikologis dan perilaku customer engagement (So et al., 2014).

Dalam menjelaskan kontribusi customer engagement untuk pengembangan hubungan pelanggan-merek, secara khusus dihubungkan antara customer engagement dan beberapa faktor hubungan pelanggan-merek termasuk keterikatan, kualitas hubungan merek, dan loyalitas merek (Hollebeek, 2011). Konsep ini diusulkan atas dasar literatur pemasaran hubungan yang menganut gagasan customer engagement (Morgan \& Hunt, 1994), yang digambarkan sebagai "hubungan pemasaran yang diperluas domainnya" (Vivek, Beatty, \& Morgan, 2012).

Hasil penelitian Nyadzayo and Khajehzadeh (2016) menyatakan ada pengaruh manajemen hubungan pelanggan terhadap loyalitas konsumen. Hasil yang sama juga ditemukan oleh (Zhang, Li, Wang, \& Wang, 2016), juga menunjukkan adanya pengaruh positif dari manajemen hubungan pelanggan dengan loyalitas. Meskipun demikian ketika manajemen hubungan dengan pelanggan dijadikan sebagai variabel moderasi dengan pengukuran melalui keanggotaan, manajemen hubungan pelanggan tidak memperkuat loyalitas pelanggan (Filipe, 
Marques, \& de Fátima Salgueiro, 2017). Hasil penelitian lain juga menunjukkan bahwa kegiatan manajemen hubungan pelanggan melalui penerapan kartu keanggotaan di toko kelontong tidak berpengaruh secara langsung terhadap loyalitas pelanggan (Filipe et al., 2017).

Berdasarkan penelitian (Nyadzayo \& Khajehzadeh, 2016; Zhang et al., 2016) dibandingkan dengan penelitian (Filipe et al., 2017) menunjukkan hasil yang berbeda atau adanya research gap dalam penelitian tersebut. Adanya research gap tersebut perlu disusun model baru dengan memasukkan variabel baru kedalam model. Variabel yang dimasukkan adalah variabel yang ada kerterkaitan dengan variabel yang dibahas sebelumnya. Salah satu variabel yang dimasukkan dalam model adalah keterikatan pelanggan (customer engagement), karena berdasarkan penelitian Dwivedi (2015) juga menunjukkan adanya pengaruh consumer brand engagement terhadap loyalty intention. Penelitian lain menunjukkan adanya pengaruh positif dari manajemen hubungan pelanggan dalam era web sosial berpengaruh positif terhadap keterikatan pelanggan di Sektor Perbankan Ritel (Giannakis-Bompolis \& Boutsouki, 2014). Berdasarkan latar belakang masalah tersebut di atas, maka dapat dirumuskan pertanyaan penelitian yaitu apakah ada pengaruh manajemen relasional nasabah terhadap loyalitas nasabah, apakah ada pengaruh manajemen relasional nasabah terhadap keterikatan nasabah, apakah ada pengaruh keterikatan nasabah terhadap loyalitas nasabah dan apakah keterikatan nasabah dapat berfungsi sebagai variabel mediasi antara manajemen relasional nasabah dengan loyalitas nasabah.

\section{TINJAUAN PUSTAKA DAN PERUMUSAN HIPOTESIS}

\section{Tinjauan Pustaka}

\section{Manajemen relasional nasabah}

CRM merupakan proses yang dinamis dari menata sebuah hubungan pelanggan-perusahaan dimana pelanggan memilih untuk melanjutkan perubahan yang berguna dan dijauhkan dari partisipasi dalam perubahan yang tidak menguntungkan perusahaan (Bergeron, 2004). Manajemen hubungan pelanggan diartikan sebagai integrasi dari strategi penjualan, pemasaran, dan pelayanan yang terkoordinasi (Kalakota \& Robinson, 2001). Dengan demikian dapat diambil kesimpulan berdasarkan beberapa definisi diatas bahwa customer relationship management merupakan usaha yang dilakukan oleh perusahaan untuk menjaga para pelanggannya agar selalu melakukan transasksi di perusahaan tersebut melalui usaha pemahaman, peningkatan pelayanan dan pemberian kepuasan yang melebihi harapan dari pelanggan tersebut.

Implementasi CRM menurut Anton and Petouhoff (2001), dalam persaingan saat ini banyak produk yang ditawarkan mudah datang dan pergi. Bagi perusahaan baik skala besar maupun kecil, asset yang terpenting dengan nilai jangka panjang yang terukur adalah kesetiaan pelanggan dan one-to-one customer relationship. CRM diimplementasikan sebagai kemampuan perusahaan mengestimasi kedepan dan bertindak untuk menciptakan pelanggan yang setia. Dalam bukunya, Anton dan Petouhoff menjelaskan mengenai bagaiman people, process, dan technology bisa membantu tidak hanya untuk memprediksi masa yang akan datang, tetapi juga dengan informasi dari percobaan gagal atau suksesnya suatu bisnis.

Berdasarkan apa yang dikemukakan oleh (Anton \& Petouhoff, 2001) di atas dapat disimpulkan sub variabel dari customer relationship management ini yaitu

people adalah semua pihak yang terlibat dalam aktivitas penyampaian jasa, meliputi karyawan perusahaan, pelanggan, dan pelanggan lain di dalam lingkungan jasa, process yaitu prosedur, mekanisme, dan alur dalam aktivitas dari penyampaian jasa dan technology, yaitu menyusun sumber data pelanggan mulai dari system operasi hingga transaksi yang memfasilitasi kegiatan jasa. 
Indikator yang digunakan untuk mengukur manajemen hubungan pelanggan adalah komitmen pelanggan, pengalaman nasabah, pendekatan proses, kehandalan dan orientasi teknologi.

\section{Keterikatan nasabah}

Customer engagement (CE) diartikan sebagai kondisi psikologis yang terjadi berdasarkan pengalaman interaktif pelanggan dan co-creative dengan agen atau objek fokal (misalnya, merek) dalam hubungan layanan fokus. Itu terjadi di bawah satu kondisi yang bergantung pada konteks yang menghasilkan tingkat CE yang berbeda; dan ada sebagai proses, dinamis iteratif dalam hubungan layanan yang nilai co-create. CE memainkan peran sentral dalam jaringan nomological yang mengatur hubungan layanan di mana konsep relasional lainnya (misalnya, keterikatan, kesetiaan) adalah anteseden dan / atau konsekuensi dalam proses CE yang berulang. Ini adalah konsep multidimensi yang tunduk pada konteks dan / atau ekspresi spesifik pemangku kepentingan dari dimensi kognitif, emosi dan / atau perilaku yang relevan (Brodie et al., 2011).

Dalam penelitian Calder, Malthouse, and Schaedel (2009) keterikatan dijadikan dua dimensi yaitu keterikatan pribadi dan keterikatan interaktif. Keterikatan pribadi dimanifestasikan dalam pengalaman yang mirip dengan yang dimiliki orang dengan surat kabar dan majalah. Keterikatan Sosial-Interaktif lebih terkait erat dengan web, aspek-aspeknya dapat ditemukan untuk media lain. Sprott, Czellar, and Spangenberg (2009) menjelaskan tentang brand engagement in self-concept, dalam penjelasannya menyatakan kecenderungan seseorang untuk memasukkan merek favoritnya sendiri ke dalam konsep-diri. Van Doorn et al. (2010) menulis tentang perilaku keterikatan konsumen, yaitu manifestasi perilaku pelanggan terhadap merek atau perusahaan, di luar pembelian, yang dihasilkan dari kendali motivasi. Hollebeek, Glynn, and Brodie (2014) membahas tentang consumer brand engagement, dan mendefinisikannya sebagai aktivitas kognitif, emosional, dan perilaku yang berkaitan dengan emosi yang dipengaruhi oleh valensi positif selama atau terkait dengan interaksi merek konsumen. Vivek et al. (2012) mendefinisikan consumer engagement sebagai tingkat interaksi dan koneksi pelanggan (atau calon pelanggan) dengan merek atau penawaran atau kegiatan perusahaan, sering kali melibatkan orang lain di jejaring sosial yang dibuat di sekitar merek atau penawaran atau aktivitas. Dwivedi (2015) menjelaskan consumer brand engagement sebagai keadaan pikiran konsumen yang positif, memuaskan, dan menggunakan merek yang dicirikan oleh kekuatan, dedikasi, dan penyerapan.

So et al. (2014) mendefinisikan customer engagement sebagai hubungan pelanggan secara pribadi untuk merek seperti yang dimanifestasikan dalam respon kognitif, afektif dan perilaku di luar pembelian dan konsep customer engagement sebagai konstruksi tingkat tinggi yang terdiri dari lima faktor utama, termasuk antusiasme (atau semangat), perhatian, penyerapan, interaksi, dan identifikasi. Terdapat lima dimensi untuk mengukur customer engagement yaitu enthusiasm, attention, absorption, interaction dan identification (So et. al., 2014 b). Enthusiasm mencerminkan tingkat kegembiraan dan ketertarikan pelanggan terhadap suatu merek. Attention menjelaskan tingkat perhatian pelanggan terhadap merek. Absorption menggambarkan keadaan menyenangkan pelanggan mencurahkan pikirannya pada merek dan interaction menunjukkan interaksi yang terjadi antara pelanggan dengan merek maupun pelanggan lain. Identification mencerminkan tingkat rasa memiliki atau kesatuan pelanggan terhadap merek.

Beberapa peneliti mengusulkan konsekuensi customer engagement yaitu kepuasan, kepercayaan dan loyalitas (Brodie et al., 2011; Hollebeek, 2011).

Indikator yang digunakan adalah ketertarikan pelanggan terhadap bank, perhatian pelanggan terhadap bank, menggunakan produk dan layanan bank, menunjukkan interaksi yang terjadi antara pelanggan dengan bank, dan mencerminkan rasa memiliki pelanggan terhadap bank.

\section{Loyalitas}


Loyalitas adalah komitmen pelanggan untuk berlangganan kembali atau melakukan pembelian secara terus menerus atas produk atau jasa di masa yang akan datang, walaupun pengaruh situasi dan usaha-usaha pemasaran dapat menyebabkan perubahan perilaku (Oliver, 1999). Loyalitas pelanggan merupakan salah satu ukuran keberhasilan strategi pemasaran. Oleh karena itu, pengembangan, pemeliharaan dan peningkatan loyalitas konsumen tetap menjadi fokus utama dari sebagian besar kegiatan pemasaran sebuah perusahaan (Dick \& Basu, 1994; Nyadzayo \& Khajehzadeh, 2016). Menurut definisi, kesetiaan adalah keinginan kuat untuk terusmenerus membeli lagi atau mengulang ulang layanan produk tertentu di masa depan (Oliver, 1999). Pelanggan setia membantu perusahaan untuk menurunkan biaya pemasaran, mengumpulkan lebih banyak pelanggan, meningkatkan pangsa pasar secara efektif, dan bersedia membayar harga premium (Aaker, 1996; Nyadzayo \& Khajehzadeh, 2016). Loyalitas pelanggan adalah suatu bentuk hubungan yang kuat antara pelanggan dengan perusahaan (Smith \& Wright, 2004).

Konsep loyalitas pelanggan sering dikaitkan dengan perilaku (behavior) daripada sikap. Sikap positif konsumen dapat ditunjukkan melalui setia kepada produk perusahaan dan mau mereferensikan produk tersebut kepada orang lain, sedangkan sikap negatif ditunjukkan melalui perkataan negative (word of mouth) kepada orang lain dan berpindah kepada perusahaan pesaing. Kesetiaan adalah sesuatu yang timbul tanpa adanya paksaan tetapi timbul dengan sendirinya. Oleh karena itu loyalitas dapat diartikan pembentukan sikap dan pola perilaku seorang konsumen terhadap pembelian dan penggunaan produk hasil dari pengalaman mereka sebelumnya (Griffin, 2005). Dari definisi tersebut loyalitas adalah keinginan kuat pelanggan untuk tetap berlangganan atau mengkonsumsi ulang produk atau jasa terpilih sebagai sikap konsisten dimasa yang akan datang, walaupun pengaruh situasi dan usaha-usaha pemasaran dapat mempengaruhi perubahan perilaku. Indikator yang digunakan adalah mereferensikan kepada orang lain, menunjukkan tidak akan berpindah ke pesaing dan memberikan masukan untuk kemajuan bank.

\section{Perumusan Hipotesis}

Hubungan manajemen relasional nasabah dengan loyalitas nasabah.

CRM merupakan suatu rangkaian kegiatan sistematik yang dikelola sebagai usaha untuk lebih memahami, menarik perhatian, dan mempertahankan loyalitas pelanggan yang menguntungkan demi mencapai pertumbuhan perusahaan yang sehat. CRM merupakan serangkaian aktivitas berorientasi pelanggan yang didukung oleh strategi dan teknologi organisasi, dan dirancang untuk meningkatkan interaksi pelanggan untuk membangun kesetiaan pelanggan dan meningkatkan laba seiring waktu (Padmavathy, Balaji, \& Sivakumar, 2012). Pendekatan yang berpusat pada pelanggan merupakan faktor keberhasilan yang penting untuk bisnis. Strategi $C R M$ yang baik dapat meningkatkan penjualan dengan memperbaiki hubungan dengan pelanggan, sehingga meningkatkan loyalitas pelanggan. $C R M$ merupakan kegiatan perusahaan untuk memahami kebutuhan untuk mewujudkan kepuasan yang berdampak pada loyalitas pelanggan sehingga dapat meningkatkan keuntungan perusahaan.

Perusahaan diharapkan memberikan pelayanan terbaik dan mampu untuk memahami apa yang diinginkan pelanggannya. Customer Relationship Management adalah media dalam berkomunikasi, pelanggan pada dasarnya ingin diperlakukan secara berbeda, karena pelayanan yang memuaskan akan membuat pelanggan menjadi loyal. Inti dari Customer Relationship Management tidak hanya melayani, namun karena perusahaan memiliki informasi tentang konsumen, maka perusahaan harus memberikan layanan terbaiknya, sehingga pelanggan akan menjadi loyal. 
Menurut Salami (2009) penerapan akan CRM sangatlah di perlukan di mana selain meningkatkan pelayanan tetapi juga memperbaiki dan mengelola sesuai dengan harapan dan loyalitas konsumen, hal ini akan membuat CRM berperan lebih efektif. Penelitian tentang efektivitas CRM dilakukan oleh (Padmavathy et al., 2012). CRME didefinisikan melalui perspektif berorientasi proses terintegrasi yang berpusat pada tiga elemen yaitu, teknologi informasi, manajemen hubungan dan iklim organisasi. Teknologi informasi yang berfokus pada pelanggan (CFIT) menandai teknologi dan sistem informasi; manajemen hubungan menunjukkan aktivitas hubungan perusahaan; dan iklim organisasi yang berfokus pada pelanggan (CFOT) mengacu pada fokus perusahaan pada pelanggan.16-item CRME tiga dimensi diuji dan divalidasi menggunakan survei dari 231 perusahaan bisnis termasuk beberapa lembaga jasa keuangan.Dimensi ini menyarankan bahwa investasi CRM harus diarahkan untuk meningkatkan aktivitas hubungan, menambah $\mathrm{TI}$, dan mengembangkan iklim organisasi yang mendorong interaksi dan layanan pelanggan.

Menurut penelitian terdahulu yang dilakukan oleh Nyadzayo and Khajehzadeh (2016) menyatakan ada pengaruh manajemen hubungan pelanggan terhadap loyalitas konsumen, demikian juga dengan penelitian Zhang et al. (2016). Studi tersebut menjelaskan bahwa CRM dapat menciptakan image perusahaan yang positif di hati konsumen. Strategi yang dilakukan perusahaan mampu membentuk tingkat loyalitas pelanggan yang merasa puas dengan kinerja perusahaan. Berdasarkan penelitian (Padmavathy et al., 2012) CRM disusun atas beberapa dimensi yaitu organizational commitment, customer experience, process-driven approach, reliability dan technology orientation. Berdasarkan hasil penelitian terdahulu tersebut maka disusun hipotesis penelitian:

$\mathrm{H}_{1}$ : Manajemen relasional nasabah berpengaruh positif terhadap variabel loyalitas nasabah.

Hubungan manajemen relasional nasabah terhadap keterikatan nasabah.

Jalinan hubungan yang baik antara perusahaan dengan konsumen dapat digunakan untuk iklan, promosi penjualan, public relation, dan pemasaran langsung untuk menciptakan cara yang lebih efisien dan efektif dalam mendapatkan konsumen (Copulsky \& Wolf, 1990). Customer relationship management mampu menciptakan kekuatan keinginan dari pelanggan dengan tekanan teknologi informasi untuk memberikan kepuasan pada nasabah (Too et al., 2001). Hubungan baik dengan pelanggan dapat digunakan untuk meningkatkan keterikatan konsumen, sebagaimana hasil studi ilmiah yang menjelaskan adanya pengaruh positif dari manajemen hubungan pelanggan dalam era web sosial terhadap keterikatan pelanggan di Sektor Perbankan Ritel (Giannakis-Bompolis \& Boutsouki, 2014). Berdasarkan penelitian (Padmavathy et al., 2012) CRM disusun atas beberapa dimensi yaitu organizational commitment, customer experience, process-driven approach, reliability dan technology orientation. Berdasarkan hasil penelitian terdahulu tersebut hal tersebut maka disusun hipotesis penelitian:

$\mathrm{H}_{2}$ : Manajemen relasional nasabah berpengaruh positif terhadap variabel keterikatan nasabah.

\section{Hubungan keterikatan nasabah terhadap loyalitas nasabah}

Keterikatan pelanggan muncul dalam literatur akademis dan diskusi praktisi sebagai paradigma baru dalam penerapan customer relationship management yang bertujuan membangun kesetiaan merek. Hal ini didorong munculnya saluran interaksi baru, yaitu media sosial dan semakin populernya internet, yang memungkinkan perusahaan dapat berinteraksi lebih intensif dengan pelanggannya. Namun, penelitian empiris tentang customer engagement masih relatif 
terbatas. Studi ini bertujuan menguji pengaruh customer engagement terhadap loyalitas merek yang dimediasi kepuasan pelanggan dan kepercayaan merek pada jasa operator telepon seluler.

Beberapa ilmuwan mengusulkan konsekuensi dari customer engagement yaitu kepuasan, kepercayaan dan loyalitas (Brodie et al., 2011; Hollebeek, 2011). Beberapa peneliti pemasaran telah mengembangkan konsep multidimensional customer engagement (Brodie et al., 2011; Hollebeek, 2011; Verhoef, Reinartz, \& Krafft, 2010), namun studi ini mengadopsi konsep customer engagement dari (So et al., 2014), karena secara spesifik berfokus pada industri jasa dan menawarkan skala pengukuran yang valid untuk mengaplikasikan konsep. Customer engagement adalah hubungan personal pelanggan terhadap merek sebagai manifestasi respon kognitif, afektif dan perilaku diluar aktivitas pembelian. Terdapat lima dimensi untuk mengukur customer engagement yaitu enthusiasm, attention, absorption, interaction dan identification. Enthusiasm mencerminkan tingkat kegembiraan dan ketertarikan pelanggan terhadap merek. Attention menjelaskan tingkat perhatian pelanggan terhadap merek. Absorption menggambarkan situasi menyenangkan pelanggan mencurahkan pikirannya pada merek dan interaction menunjukkan interaksi yang terjadi antara pelanggan dengan merek maupun pelanggan lain. Identification adalah tingkat rasa kesatuan pelanggan terhadap merek atau brand (So et al., 2014). Hubungan engagement secara intens antara pelanggan dan perusahaan dapat mempengaruhi loyalitas pelanggan, berdasarkan pada tingkat interaksi hubungan dan emosional yang dirasakan pelanggan (Sashi, 2012). Berdasarkan hubungan antar variabel dalam penelitian terdahulu tersebut maka disusun hipotesis penelitian sebagai berikut :

$\mathrm{H}_{3}$ : Variabel keterikatan nasabah berpengaruh positif terhadap variabel loyalitas nasabah.

\section{Hubungan manajemen relasional terhadap loyalitas nasabah dengan keterikatan nasabah sebagai intervening.}

Menciptakan nilai yang superior untuk perusahaan dan pelanggan melibatkan integrasi pemasaran, penjualan, layanan pelanggan, dan rantai suplai fungsi organisasi untuk mencapai efisiensi dan efektivitas yang lebih dalam memberikan nilai pelanggan. Untuk membangun hubungan dengan pelanggan secara berkelanjutan, perusahaan harus mempunyai program atau strategi dalam mengelola pelanggan potensial. Iriana and Buttle (2007) inti proses CRM meliputi tiga kegiatan atau siklus hidup pelanggan, yaitu : mendapatkan pelanggan baru (acquire), menguasai dan mempertahankan pelanggan yang ada (retain), dan mengembangkan nilai-nilai pelanggan (develop).

Customer engagement adalah perspektif baru yang penting dalam konsep customer relationship management (CRM). Customer engagement dianggap sebagai manifestasi perilaku pelanggan atas pengalaman hubungan interaksinya dengan perusahaan melalui media sosial, diluar kegiatan pembelian (Verhoef et al., 2010). Customer engagement dinyatakan sebagai kognitif, afektif, perilaku, atau sosial. Elemen-elemen kognitif dan afektif menggabungkan pengalaman dan perasaan pelanggan, dan unsur-unsur sosial dan perilaku diambil dari partisipasi oleh pelanggan saat ini dan pelanggan potensial. Sedangkan CRM digunakan sebagai alat untuk menjalin hubungan baik dengan pelanggan, serta involvement sebagai pembentuk pengalaman pelanggan. Strategi customer engagement terbentuk dari interaksi dengan perusahaan yang berlangsung kontinyu dalam waktu yang lama, dengan mengajak customer terlibat dan berpartisipasi kedalam events. Dari terbentuknya customer engagement akan mempengaruhi kesetiaan pelanggan terhadap perusahaan. Berdasarkan uraian tersebut maka disusun hipotesis penelitian sebagai berikut:

$\mathrm{H}_{4}$ : Manajemen relasional nasabah berpengaruh positif terhadap variabel loyalitas nasabah melalui keterikatan nasabah sebagai intervening. 


\section{METODE PENELITIAN}

Jenis penelitian ini penelitian survey, yaitu untuk memperoleh data penelitian dilakukan terhadap nasabah prioritas PT Bank Central Asia Tbk Cabang Purwokerto. Populasi dalam penelitian ini adalah seluruh nasabah prioritas PT Bank Central Asia Tbk. Cabang Purwokerto yang masih aktif berjumlah 300 nasabah.

Ukuran sampel ditentukan dengan metode Slovin. Berdasarkan metode Slovin diperoleh ukuran sampel 100 responden. Pertimbangan ukuran sampel berikutnya adalah

teknik analisis data menggunakan SEM (structural equation model) membutuhkan ukuran sampel yang lebih besar dibandingkan pendekatan multivariat lainnya (Hair Jr, et. al., 2010: 661). Secara sederhana Sekaran (2003) mengatakan bahwa analisis SEM membutuhkan sampel paling sedikit 5 kali sampai dengan 10 kali jumlah parameter yang digunakan. Oleh karena itu sampel yang digunakan dalam penelitian ini adalah $(13+3)$ x 9 yaitu 144 responden. Teknik pengambilan sampel yang digunakan dalam penelitian ini adalahsimple random sampling, yaitu pemilihan sampel dimana tiap elemen populasi memiliki peluang yang sama dan diketahui untuk terpilih sebagai subjek (Sekaran \& Bougie, 2016).

Skala pengukuran yang digunakan adalah skala Likert dengan pengukuran sebagai berikut:

Kategori Sangat Tidak Setuju (STS), skor 1

Kategori Tidak Setuju (TS), skor 2

Kategori Netral (N), skor 3

Kategori Setuju (S), skor 4

Kategori Sangat Setuju (SS), skor 5

Penelitian ini menggunakan teknik analisis data structural Equation Modeling (SEM). Ada tujuh langkah yang harus dilakukan apabila menggunakan Structural Equation Modelling (SEM), yaitu (Ferdinand, 2002) : pengembangan model teoritis, pengembangan diagram alur (path diagram), konversi diagram alur ke dalam persamaan, memilih matrik input dan estimasi model, kemungkinan munculnya masalah identifikasi, dan evaluasi kriteria goodness of fit .

Pengujian hipotesis pertama sampai dengan hipotesis ketiga dilakukan melihat nilai Critical Ratio (CR),(Ferdinand, 2002). Hipotesis diterima apabila koefisien jalur positif dan CR > $\mathrm{t}$ tabel atau $\mathrm{p}<0,05$. Pengujian hipotesis keempat yaitu customer engagement memediasi pengaruh customer relationship management terhadap loyalty dilakukan dengan prosedur yang dikembangkan oleh Sobel (Ghazali, 2013) dan dikenal dengan uji Sobel (Sobel test).

\section{HASIL DAN PEMBAHASAN}

\section{Uji kriteria goodness of fit}

Penelitian ini menguji hipotesis dengan teknik analisis data structural Equation Modeling. Semua indikator yang digunakan dalam penelitian ini sudah teruji validitas dan reliabilitas serta teruji normalitasnya, sehingga langsung dilakukan pembahasan hasil analisisnya. Pembahasan dilakukan pada goodness of fit dan pengujian hipotesis hubungan antar variabel. Adapun goodness of fit dapat dilihat pada Tabel 1. 
Tabel 1. Indeks pengujian kelayakan model structural equation modelling

\begin{tabular}{lccc}
\hline Goodness offit index & Cut-of value & $\begin{array}{c}\text { Hasil } \\
\text { analisis }\end{array}$ & $\begin{array}{c}\text { Evaluasi } \\
\text { Model }\end{array}$ \\
\hline$\chi^{2}$-Chi-square & 81,38 & 71,254 & Baik \\
Significancy probability & $\geq 0.05$ & 0,197 & Baik \\
RMSEA & $\leq 0.08$ & 0,032 & Baik \\
GFI & $\geq 0.90$ & 0,931 & Baik \\
AGFI & $\geq 0.90$ & 0,899 & Marginal \\
CMIN/DF & $\leq 2.00$ & 1,149 & Baik \\
TLI & $\geq 0.95$ & 0,991 & Baik \\
CFI & $\geq 0.95$ & 0,993 & Baik \\
\hline
\end{tabular}

Berdasarkan Tabel 1 dapat diketahui uji goodness of fit dilakukan dengan $\chi^{2}$-Chi-square, Significancy probability, RMSEA, GFI, AGFI, CMIN/DF, TLI dan CFI. Hasil uji menunjukkan dari delapan kriteria goodness of fit terdapat tujuh yang menyatakan bahwa model yang digunakan dalam penelitian ini baik. Hanya satu yang menyatakan marginal atau lebih rendah dari nilai yang baik, yaitu kriteria AGFI dengan nilai AGFI 0,899, sedangkan nilai minimal 0,9. Meskipun marginal tetapi marginalnya selisih tipis dan pembulatanya pun sebesar 0,9. Jadi nilai AGFI yang marginal tidak menjadi masalah dalam penelitian ini, karena hasil akhir yang diharapkan bukan hanya sebuah model strukltrual, tetapi juga hubungan antar variabel dalam penelitian ini yang tersusun dalam hipotesis penelitian.

\section{Structural Equation Modelling (SEM)}

Hasil pengolahan analisis structural equation modelling (SEM) dapat dilihat pada Gambar 1 dan Tabel 2.

Tabel 2. Hasil analisis structural equation modelling

\begin{tabular}{ccccrrr}
\hline Variabel & & & Estimate & S.E. & C.R. & P \\
\hline CE & $<---$ & CRM & 0,256 & 0,083 & 2,868 & 0,004 \\
LOY & $<---$ & CE & 0,209 & 0,071 & 2,047 & 0,041 \\
LOY & $<---$ & CRM & 0,212 & 0,063 & 2,168 & 0,030 \\
\hline
\end{tabular}

Keterangan:

$\mathrm{CE}=$ Customer engagement

$\mathrm{CRM}=$ Customer relationship management

LOY = Customer loyalty

Berdasarkan Gambar 1 dan Tabel 2 dapat dibuat persamaan struktural sebagai berikut:

$\mathrm{CE}=0,256 \mathrm{CRM}+\mathrm{Z}_{1}$

$\mathrm{LOY}=0,212 \mathrm{CRM}+0,209 \mathrm{CE}+\mathrm{Z}_{2}$

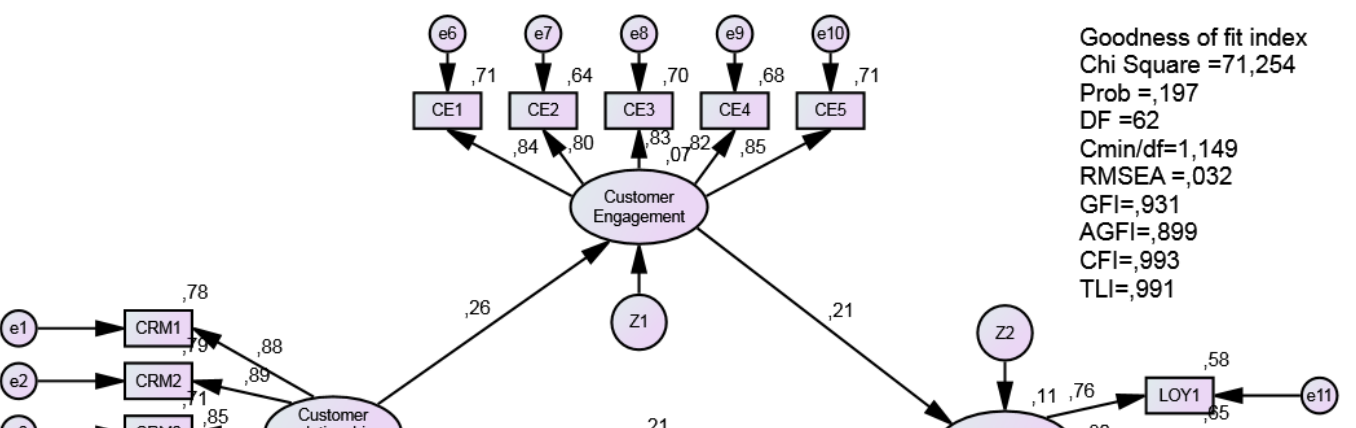


Gambar 1. Hasil analisis structural equation modelling

\section{Analisis mediasi}

Analisis mediasi dilakukan untuk menguji customer engagement dalam memediasi hubungan antara customer relationship management dengan loyalitas. Hasil uji dapat dilihat pada Tabel 3

Tabel 3. Hasil uji mediasi

\begin{tabular}{lllll}
\hline Variabel eksogen & Variabel Endogen & Uji Sobel & p-value & Keterangan \\
\hline $\begin{array}{l}\text { customer } \\
\text { relationship } \\
\text { management }\end{array}$ & Loyalty & 2,1294 & 0,0166 & Memediasi \\
\hline
\end{tabular}

Berdasarkan Tabel 3 dapat diketahui variabel customer engagement mampu memediasi memediasi hubungan antara customer relationship management dan loyalitas nasabah, karena nilai $p$ value thitung uji Sobel kurang dari 0,05.

\section{Pembahasan}

\section{Pembahasan model}

Pembahasan model dilakukan dengan memperhatikan goodness of fit index. Beberapa kriteria yang digunakan adalah ?22-Chi-square, Significancy probability, RMSEA, GFI, AGFI, CMIN/DF, TLI dan CFI. Hasil uji menunjukkan bahwa diantara kriteria tersebut model penelitian yang digunakan sudah baik. Hal ini didasarkan atas hasil uji Chi-square, Significancy probability, RMSEA, GFI, CMIN/DF, TLI dan CFI. Diantara kriteria tersebut hanya satu yang menyatakan marginal, yaitu berdasarkan kriteria AGFI. Akan tetapi marginalnya pada nilai 0,899 atau jika dibulatkan menjadi 0,9, artinya nilai AGFI tersebut tidaklah buruk dalam model ini, apalagi hasil uji secara parsial menunjukkan adanya pengaruh yang signifikan dari variabel yang diteliti. Adapun pengaruh antar variabel tersebut dapat dilihat pada pembahasan di bawah ini.

\section{Pembahasan hasil uji hipotesis}

Pengujian hipotesis dilakukan dengan menggunakan analisis structural equation modelling, tercantum dalam Gambar 1. Berdasarkan Gambar 1 dapat diketahui nilai koefisien jalur. Nilai koefisien jalur dan signifikansi selengkapnya dapat dilihat pada Tabel 2.

\section{Pengaruh manajemen relasional nasabah terhadap variabel loyalitas nasabah}

Nilai estimasi koefisien jalur variabel customer relationship management terhadap loyalty sebesar 0,212 dengan nilai probability sebesar 0,030. Karena nilai koefisien jalur positif dan nilai probabilitas kurang dari 0,05 maka dapat disimpulkan bahwa customer relationship management berpengaruh positif terhadap loyalty, yaitu semakin baik customer relationship management yang maka akan semakin loyal nasabah BCA. 


\section{Pengaruh manajemen relasional nasabah terhadap variabel keterikatan nasabah}

Nilai estimasi koefisien jalur variabel customer relationship management terhadap customer engagement sebesar 0,256 dengan nilai probability sebesar 0,004. Karena nilai koefisien jalur positif dan nilai probabilitas kurang dari 0,05 maka dapat disimpulkan bahwa variabel customer relationship management memiliki pengaruh yang positif terhadap customer engagement, yaitu semakin baik customer relationship management Bank BCA maka akan mengakibatkan customer engagement meningkat.

\section{Pengaruh keterikatan nasabah terhadap loyalitas nasabah}

Nilai estimasi koefisien jalur customer engagement terhadap loyalitas sebesar 0,209 dengan nilai probability sebesar 0,209 . Karena koefisien jalur positif dan nilai probabilitas kurang dari 0,05 maka dapat disimpulkan bahwa variabel customer engagement memiliki pengaruh yang positif terhadap loyalty, artinya semakin baik customer engagement maka semakin loyal nasabah BCA.

\section{Hubungan manajemen relasional terhadap loyalitas nasabah dengan keterikatan nasabah sebagai intervening}

Berdasarkan hasil analisis mediasi pada Tabel 3 dapat diketahui nilai thitung pengujian mediasi antara customer relationship management, customer engagement dan loyalitas sebesar 2,0762 dengan signifikansi 0,0166. Nilai signifikansi kurang dari 0,05, sehingga dapat diartikan customer engagement dapat memediasi hubungan variabel customer relationship management dan loyalitas nasabah Bank BCA.

\section{Pembahasan hasil penelitian}

\section{Pengaruh manajemen relasional nasabah terhadap variabel loyalitas nasabah}

Berdasarkan hasil analisis data dapat diketahui terdapat pengaruh manajemen relasional nasabah terhadap variabel loyalitas nasabah. Hal ini menunjukkan semakin baik jalinan hubungan antara nasabah dengan perbankan akan membuat nasabah semakin loyal. Jalinan hubungan antara perusahaan dengan nasabah penting dilakukan karena jalinan hubungan dengan nasabah merupakan suatu rangkaian kegiatan yang terkelola sebagai usaha untuk semakin memahami, menarik perhatian, dan mempertahankan loyalitas pelanggan yang menguntungkan demi mencapai pertumbuhan perusahaan yang sehat. Jalinan hubungan dengan pelanggan merupakan serangkaian aktivitas berorientasi pelanggan yang didukung oleh strategi dan teknologi organisasi, dan dirancang untuk meningkatkan interaksi pelanggan untuk membangun kesetiaan pelanggan dan meningkatkan laba seiring waktu (Padmavathy et al., 2012). Adanya pengaruh jalinan hubungan dengan pelanggan ini mendukung penelitian sebalumnya yang dilakukan oleh Nyadzayo and Khajehzadeh (2016) menyatakan ada pengaruh manajemen hubungan pelanggan terhadap loyalitas konsumen, demikian juga dengan penelitian Zhang et al. (2016).

\section{Pengaruh hubungan manajemen relasional nasabah terhadap keterikatan nasabah.}

Hasil analisis menunjukkan adanya pengaruh hubungan manajemen relasional nasabah terhadap keterikatan nasabah. Hal ini berarti semakin baik hubungan nasabah dengan perusahaan akan semakin kuat rasa keterikatan nasabah dengan perusahaan. Jalinan hubungan yang baik antara perusahaan dengan konsumen dapat digunakan untuk advertising, promosi penjualan, public relation, dan direct marketing untuk menciptakan cara yang lebih efisien dan efektif dalam mendapatkan konsumen (Copulsky \& Wolf, 1990). Customer relationship management mampu memberdayakan kekuatan keinginan pelanggan dengan tekanan teknologi informasi untuk memberikan kepuasan pada nasabah (Too et al., 2001). Hasil penelitian ini mendukung penelitian terdahulu yang menyatakan hubungan baik dengan pelanggan dapat digunakan untuk meningkatkan keterikatan konsumen, sebagaimana hasil 
penelitian yang menunjukkan adanya pengaruh positif dari manajemen hubungan pelanggan dalam era web sosial terhadap keterikatan pelanggan di Sektor Perbankan Ritel (GiannakisBompolis \& Boutsouki, 2014).

\section{Pengaruh keterikatan nasabah terhadap loyalitas nasabah}

Berdasarkan hasil analisis data dapat diketahui bahwa keterikatan nasabah berpengaruh terhadap loyalitas nasabah. Hal ini berarti semakin kuat keteraikatan nasabah dengan bank maka akan membuat nasabah semakin loyal. Hal ini sesuai dengan pernyataan (Brodie et al., 2011; Hollebeek, 2011) yaitu konsekuensi dari customer engagement yaitu kepuasan, kepercayaan dan loyalitas. Customer engagement adalah hubungan personal pelanggan terhadap merek sebagai manifestasi respon kognitif, afektif dan perilaku diluar aktivitas pembelian. Ada lima dimensi untuk mengukur customer engagement yaitu enthusiasm, attention, absorption, interaction dan identification. Hubungan engagement secara intens antara pelanggan dan perusahaan dapat mempengaruhi loyalitas pelanggan, berdasarkan pada tingkat interaksi hubungan dan emosional yang dirasakan pelanggan (Sashi, 2012).

\section{Hubungan manajemen relasional terhadap loyalitas nasabah dengan keterikatan nasabah sebagai intervening}

Hasil analisis data diketahui hubungan relasional nasabah berpengaruh terhadap keterikatan nasabah dan loyalitas. Demikian juga dengan keterikatan nasabah berpengaruh terhadap loyalitas nasabah. Adanya pengaruh tersebut menjadikan keterikatan nasabah dapat menjadi variabel mediasi antara hubungan relasional nasabah dengan loyalitas nasabah. Keterikatan nasabah dianggap sebagai manifestasi perilaku nasabah atas pengalaman hubungan interaksinya dengan perusahaan perbankan diluar aktivitas pembelian (Verhoef et al., 2010). Oleh karena itu pengalaman dalam kaitannya hubungan dengan nasabah perlu ditingkatkan agar nasabah menjadi loyal. Hal ini juga sejalan dengan konsep hubungan perusahaan dengan pelanggan dilakukan untuk mempertahankan pelanggan yang sudah ada dan mencoba mendapatkan pelanggan baru atas referensi pelanggan lama yang ada dan sudah merasakan pengalaman yang menarik saat bertransaksi dengan perusahaan.

\section{KESIMPULAN}

Berdasarkan hasil analisis data dengan teknik analisis SEM AMOS dapat disimpulkan sebagai berikut : manajemen relasional nasabah berpengaruh positif terhadap loyalitas nasabah, manajemen relasional nasabah berpengaruh positif terhadap keterikatan nasabah, keterikatan nasabah berpengaruh positif terhadap loyalitas nasabah dan keterikatan nasabah berfungsi sebagai variabel mediasi antara manajemen relasional nasabah dengan loyalitas nasabah.

Implikasi manajerial dari penelitian ini adalah loyalitas nasabah dapat ditingkatkan dengan membangun keterikatan nasabah dan membangun hubungan relasional dengan nasabah. CRM adalah senjata BCA untuk mendapatkan komunikasi yang baik dengan nasabah. BCA diharapkan selalu melakukan inovasi teknologi terhadap layanan digital banking untuk mendukung layanan berkualitas seperti internet banking, mobile banking dan kemudahan lainnya. Demikian juga dengan keterikatan nasabah dapat ditingkatkan dengan membangun hubungan relasional dengan nasabah dengan lebih baik. Adanya peran keterikatan nasabah untuk membangun loyalitas maka perusahaan perlu mengutamakan membuat nasabah lebih terikat, sehingga pada akhirnya akan membuat nasabah menjadi lebih loyal. BCA diharapkan sering mengadakan customer gathering dimana sama sekali tidak ada penjualan dan dilakukan sebagai bentuk apresiasi BCA serta sarana engagement dengan nasabah. 
Dalam setiap penelitian memiliki kekurangan dan keterbatasan. Keterbatasan dalam penelitian ini yaitu responden yang diteliti sebagian besar sudah menjadi nasabah Bank BCA lebih dari 5 tahun. Hal ini menunjukkan secara umum responden adalah nasabah loyal Bank BCA. Untuk penelitian yang akan datang, diharapkan dapat diperoleh ukuran sampel yang proporsional antara menjadi nasabah kurang dari 5 tahun dan lebih dari 5 tahun, sehingga dapat diperoleh dua kelompok untuk dianalisis pada nasabah lama dan nasabah baru. Ini artinya lamanya menjadi nasabah bisa menjadi variabel kontrol.

\section{DAFTAR PUSTAKA}

Aaker, D. A. (1996). Measuring brand equity across products and markets. California management review, 38(3), 102.

Anton, J., \& Petouhoff, N. L. (2001). Customer relationship management: The bottom line to optimizing your ROI (NetEffect Series): Prentice-Hall, Inc.

Bennett, R. (1996). Relationship formation and governance in consumer markets: transactional analysis versus the behaviourist approach. Journal of Marketing Management, 12(5), 417-436.

Bergeron, B. (2004). Essentials of CRM: A guide to customer relationship management (Vol. 14): John Wiley \& Sons.

Bijmolt, T. H., Leeflang, P. S., Block, F., Eisenbeiss, M., Hardie, B. G., Lemmens, A., \& Saffert, P. (2010). Analytics for customer engagement. Journal of service research, 13(3), 341-356.

Blois, K. J. (1996). Relationship marketing in organizational markets: when is it appropriate? Journal of Marketing Management, 12(1-3), 161-173.

Brodie, R. J., Hollebeek, L. D., Jurić, B., \& Ilić, A. (2011). Customer engagement: Conceptual domain, fundamental propositions, and implications for research. Journal of service research, 14(3), 252-271.

Brodie, R. J., Ilic, A., Juric, B., \& Hollebeek, L. (2013). Consumer engagement in a virtual brand community: An exploratory analysis. Journal of Business Research, 66(1), 105114.

Calder, B. J., Malthouse, E. C., \& Schaedel, U. (2009). An experimental study of the relationship between online engagement and advertising effectiveness. Journal of interactive marketing, 23(4), 321-331.

Chen, J.-S., Yen, H. R., Li, E. Y., \& Ching, R. K. (2009). Measuring CRM effectiveness: Construct development, validation and application of a process-oriented model. Total Quality Management, 20(3), 283-299.

Cho, Y., Im, I., Hiltz, S. R., \& Fjermestad, J. (2001). Causes and outcomes of online customer complaining behavior: Implications for customer relationship management (CRM). AMCIS 2001 Proceedings, 175. 
Copulsky, J. R., \& Wolf, M. J. (1990). Relationship marketing: positioning for the future. Journal of Business Strategy, 11(4), 16-20.

Dick, A. S., \& Basu, K. (1994). Customer loyalty: toward an integrated conceptual framework. Journal of the Academy of marketing Science, 22(2), 99-113.

Dwivedi, A. (2015). A higher-order model of consumer brand engagement and its impact on loyalty intentions. Journal of Retailing and Consumer Services, 24, 100-109.

Ferdinand, A. (2002). Structural equation modeling in management research. Fakultas Ekonomi UNDIP: Semarang.

Filipe, S., Marques, S. H., \& de Fátima Salgueiro, M. (2017). Customers' relationship with their grocery store: Direct and moderating effects from store format and loyalty programs. Journal of Retailing and Consumer Services, 37, 78-88.

Ghazali, I. (2013). Aplikasi Analisis Multivariate Dengan Program IBM SPSS 21 Update PLS Regresi. Semarang: Badan Penerbit Universitas Diponegoro.

Giannakis-Bompolis, C., \& Boutsouki, C. (2014). Customer relationship management in the era of social web and social customer: an investigation of customer engagement in the Greek retail banking sector. Procedia-Social and Behavioral Sciences, 148, 67-78.

Griffin, J. (2005). Customer Loyalty: Menumbuhkan Dan Mempertahankan Pelanggan, Penerbit Erlangga: Jakarta.

Hollebeek, L. D. (2011). Demystifying customer brand engagement: Exploring the loyalty nexus. Journal of Marketing Management, 27(7-8), 785-807.

Hollebeek, L. D., Glynn, M. S., \& Brodie, R. J. (2014). Consumer brand engagement in social media: Conceptualization, scale development and validation. Journal of interactive marketing, 28(2), 149-165.

Iriana, R., \& Buttle, F. (2007). Strategic, operational, and analytical customer relationship management: attributes and measures. Journal of Relationship Marketing, 5(4), 23-42.

Jham, V., \& Khan, K. M. (2008). Determinants of performance in retail banking: Perspectives of customer satisfaction and relationship marketing. Singapore Management Review, $30(2), 35$.

Jiang, H., \& Zhang, Y. (2016). An investigation of service quality, customer satisfaction and loyalty in China's airline market. Journal of air transport management, 57, 80-88.

Kalakota, R., \& Robinson, M. (2001). E-Business 2.0 Roadmap for Success, Massachusetts: Addsion Wesley Longman Inc.

Khoe, Y. T. (1997). Relationship Marketing Strategi Kemampulabaan Jangka Panjang. Usahawan No. 03. Th. XXVI. Maret.

Kotler, P., \& Keller, L. (2007). Kevin. 2007. Marketing Management. Praha: Grada Publishing. 
Lee-Kelley, L., Gilbert, D., \& Mannicom, R. (2003). How e-CRM can enhance customer loyalty. Marketing Intelligence \& Planning, 21(4), 239-248.

Morgan, R. M., \& Hunt, S. D. (1994). The commitment-trust theory of relationship marketing. The journal of marketing, 20-38.

Nyadzayo, M. W., \& Khajehzadeh, S. (2016). The antecedents of customer loyalty: A moderated mediation model of customer relationship management quality and brand image. Journal of Retailing and Consumer Services, 30, 262-270.

Oliver, R. L. (1999). Whence consumer loyalty? The journal of marketing, 33-44.

Padmavathy, C., Balaji, M., \& Sivakumar, V. (2012). Measuring effectiveness of customer relationship management in Indian retail banks. International Journal of Bank Marketing, 30(4), 246-266.

Palmatier, R. W., Dant, R. P., Grewal, D., \& Evans, K. R. (2006). Factors influencing the effectiveness of relationship marketing: A meta-analysis. Journal of marketing, 70(4), 136-153.

Payne, A., \& Frow, P. (2005). A strategic framework for customer relationship management. Journal of marketing, 69(4), 167-176.

Salami, M. P. (2009). Impact of customer relationship management (CRM) in the Iran banking sector. International Journal of Organizational Innovation (Online), 2(1), 225.

Sashi, C. (2012). Customer engagement, buyer-seller relationships, and social media. Management decision, 50(2), 253-272.

Sekaran, U., \& Bougie, R. (2016). Research methods for business: A skill building approach: John Wiley \& Sons.

Sharma, S., \& Goyal, D. (2011). Critical success factors for CRM implementation: a study on Indian banks. Paper presented at the International Conference on Information Intelligence, Systems, Technology and Management.

Smith, R. E., \& Wright, W. F. (2004). Determinants of customer loyalty and financial performance. Journal of management accounting research, 16(1), 183-205.

So, K. K. F., King, C., \& Sparks, B. (2014). Customer engagement with tourism brands: Scale development and validation. Journal of Hospitality \& Tourism Research, 38(3), 304329.

Soch, H., \& Sandhu, H. (2008). Does customer relationship management activity affect firm performance? Global Business Review, 9(2), 189-206.

Sprott, D., Czellar, S., \& Spangenberg, E. (2009). The importance of a general measure of brand engagement on market behavior: Development and validation of a scale. Journal of Marketing Research, 46(1), 92-104.

Tjiptono, F. (2005). Pemasaran jasa. Malang: Bayumedia Publishing, 104. 
Too, L. H., Souchon, A. L., \& Thirkell, P. C. (2001). Relationship marketing and customer loyalty in a retail setting: a dyadic exploration. Journal of Marketing Management, 17(3-4), 287-319.

Uppal, R. (2008). Customer Relationship Management in Indian Banking Industry: New Century Pubns.

Van Doorn, J., Lemon, K. N., Mittal, V., Nass, S., Pick, D., Pirner, P., \& Verhoef, P. C. (2010). Customer engagement behavior: Theoretical foundations and research directions. Journal of service research, 13(3), 253-266.

Vanessa, G. (2007). Customer Relationship Management and Marketing Public Relations. Alfabeta. Bandung.

Vargo, S. L., \& Lusch, R. F. (2008). Why "service"? Journal of the Academy of marketing Science, 36(1), 25-38.

Verhoef, P. C., Reinartz, W. J., \& Krafft, M. (2010). Customer engagement as a new perspective in customer management. Journal of service research, 13(3), 247-252.

Vivek, S. D., Beatty, S. E., \& Morgan, R. M. (2012). Customer engagement: Exploring customer relationships beyond purchase. Journal of marketing theory and practice, 20(2), 122-146.

Zhang, R., Li, G., Wang, Z., \& Wang, H. (2016). Relationship value based on customer equity influences on online group-buying customer loyalty. Journal of Business Research, 69(9), 3820-3826. 